\title{
Air quality model for Barcelona
}

\author{
J. Lao \& O. Teixidó \\ Energy \& Air Quality Department, Barcelona Regional, Spain
}

\begin{abstract}
Some cities and metropolitan areas have a hard time complying with EU regulations regarding certain pollutant concentration levels. In 2008, Barcelona's monitoring stations reported $\mathrm{NO}_{2}$ levels above the EU limit of $40 \mu \mathrm{g} / \mathrm{m}^{3}$. This paper shows the process and results of $\mathrm{NO}_{2}$ dispersion analysis in Barcelona using 2008 as the base year, as well as the results of the 2020 forecast. Barcelona City Council has drawn up an air-quality model as part of the "PECQ" (Energy, Climate Change and Air Quality Plan for Barcelona 2011-2020) to help decision makers implement actions aimed at reducing $\mathrm{NO}_{2}$. In the first stage, a real inventory of vehicles was performed, recording over 90,000 vehicle plates and also measuring 42,000 actual emissions via Remote Sensing Devices. We discovered that the vehicles on the road are newer than the city census vehicles. We also found out that real-world vehicle emissions are 16.2\% higher than COPERT. We used GIS tools to compile the geographical inventory of emissions inside and outside the city. The base-year results show that $65.6 \%$ of $\mathrm{NO}_{2}$ concentration levels come from vehicles, $8.6 \%$ from the residential and commercial, $4.8 \%$ from industry, including heat and power production close to the city, 2.1\% from Barcelona Port, and 0.1\% from Barcelona Airport. The local background contribution was calculated as $10.1 \%$ and the regional background accounts for $8.6 \%$. The PECQ Plan will run projects from 2011 until 2020 aimed at reducing $\mathrm{NO}_{\mathrm{X}}$ emissions in various sectors. Improvements in vehicle technology are also expected. The 2020 forecast scenario shows that $\mathrm{NO}_{2}$ concentration levels will drop by $35 \%$ to reach EU standards.

Keywords: air quality, air pollution modelling, validation, Barcelona, dispersion modelling, $\mathrm{NO}_{2}, \mathrm{NO}_{X}, \mathrm{PECQ}$, emission inventory, $\mathrm{RSD}$.
\end{abstract}

\section{Introduction}

The Barcelona PECQ 2011-2020 (acronym in Catalan of Barcelona's Energy, Climate Change and Air Quality Plan [1]) is an action plan directed by Barcelona 
city council and developed by Barcelona Regional (a public company) together with the City Council. The general objectives are: to reduce the increase in energy consumption, to reduce the increase in greenhouse-gas emissions associated with the municipality, and to improve air quality in the city, especially as regards $\mathrm{NO}_{2}$ and $\mathrm{PM}_{10}$, with a specific reduction target of $26 \%$ for $\mathrm{NO}_{\mathrm{X}}$ and $39 \%$ for $\mathrm{PM}_{10}$ emissions, in order to achieve European objectives for air-quality levels.

The PECQ methodology includes a historical analysis of energy, GHG emissions and air quality in Barcelona city, plus a battery of projects and proposals for the next 10 years. It also contains the expected future scenario, including an in-depth dispersion modelling analysis of the city and its surroundings. The PECQ includes other interesting aspects such as the analysis of social attitudes towards energy consumption, and the effects of the PECQ Action Plan on the local and regional economy. The PECQ development process also included extensive consultation with citizens and stakeholders, from the design stage through to drafting of the Action Plan.

This paper will focus on the $\mathrm{NO}_{2}$ air-quality model for the city of Barcelona. We will show the methodology, validation process, results of the base case (2008) and Barcelona's expected air quality by 2020 according to the various policies and measures adopted under the PECQ Action Plan.

\section{Barcelona air quality}

Like other cities, Barcelona exceeds the annual average $\mathrm{NO}_{2}$ concentration thresholds established by the EU to protect human health. This means that cities, regions and countries must adopt new strategies, on various levels, aimed at improving air quality in metropolitan areas. This includes vehicle manufacturers, legislators, citizens, companies, and so on.

For years, Barcelona City Council and other public bodies have been working to improve air quality through various measures involving industry and power plants and by promoting renewable energy. Examples of this include the Solar Thermal Bylaw [2] of 1999 or the application of the Barcelona Energy Improvement Plan (2001-2010) [3].

Given that the main source of pollutants is road transport, Barcelona metropolitan area has made remarkable efforts to achieve a modal split change. This has included promoting the integration of public transport fares and the improvement of public transport networks (bus, metro, trams). Barcelona has also expanded the city's bicycle network and created "Bicing" - a public bicyclerental service with a very low-cost flat rate. Another measure was to increase the roll-out of parking meters for surface parking, in order to make private transport systems less competitive.

Despite all the policies designed to make public transport more attractive and to stimulate the modal split change from private vehicles to the public system, there is still some way to go, since the city does not yet fall within the air-quality standards set by Europe. The EU limit value for annual average nitrogen dioxide concentration in 2009 was $42 \mu \mathrm{g} / \mathrm{m}^{3}$ (including a tolerance margin of $2 \mu \mathrm{g} / \mathrm{m}^{3}$ 
applicable in 2009). Four out of a total of six measurement stations inside the city exceeded the annual average limit.

As shown in Figure 1, $\mathrm{NO}_{2}$ station measurements for Barcelona city and surrounding municipalities exceed $\mathrm{EU} \mathrm{NO}_{2}$ limits, meaning that new initiatives are required.

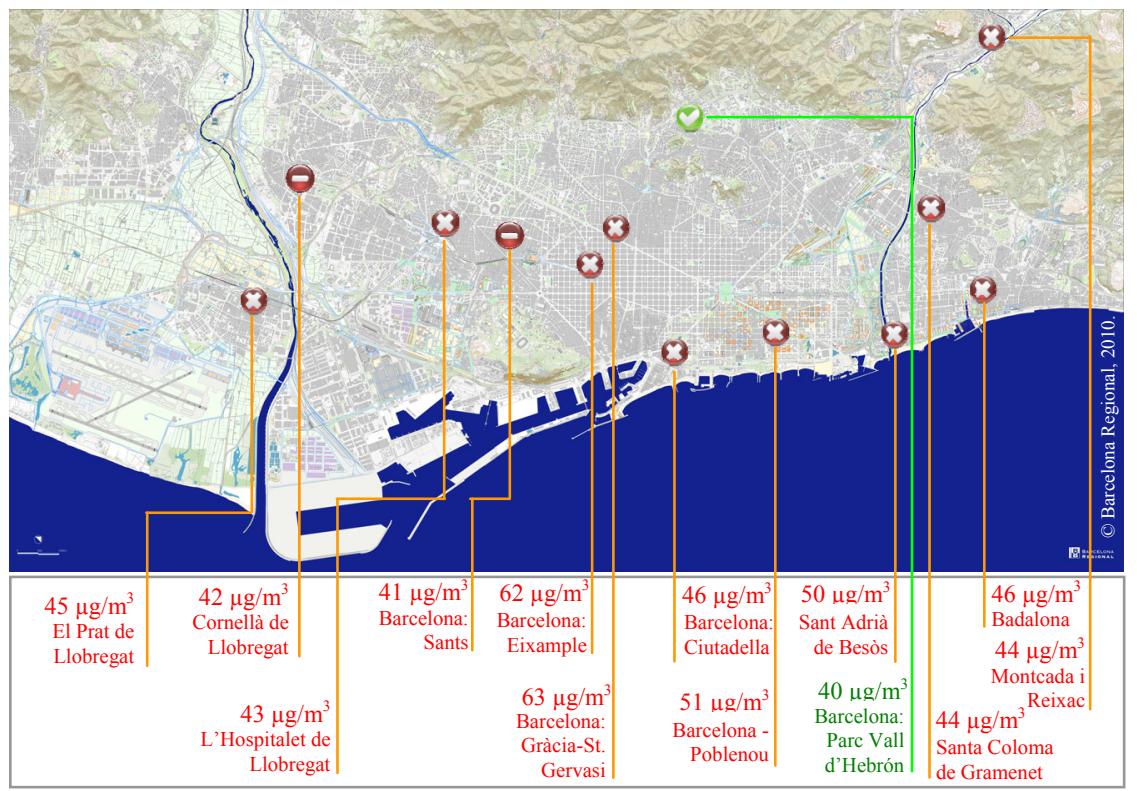

Figure 1: Annual average $\mathrm{NO}_{2}$ concentration at measurement stations in Barcelona and surroundings (2009).

\section{Barcelona urban air-dispersion model}

Within the PECQ, in order to focus the Action Plan most effectively, it was essential to determine what activities and sectors are responsible for high $\mathrm{NO}_{2}$ concentration levels. A detailed inventory of emissions by sectors has been developed for the base case year 2008 and distributed throughout the territory. This emission inventory was one of the key inputs of the Barcelona AirDispersion Model, a tool that helps decision-makers know what is happening with air quality and what needs to be done in order to improve it.

\subsection{Methodology}

For atmospheric dispersion modelling we used ADMS-Urban [4], developed by CERC in the UK. ADMS-Urban allowed us to calculate $\mathrm{NO}_{2}$ concentration levels based on a Gaussian dispersion model with photochemical reactions and an integrated street canyon model. The entire model is fully integrated in a 
Geographical Information System (GIS) database of emission sources, terrain configurations and other relevant aspects.

The main features of the dispersion model used are:

- Specific dispersion model for urban and metropolitan areas with resolution down to street level.

- Includes a meteorological pre-processing model.

- Uses the "FlowStar" module, a processing module designed for hourly flows and turbulence for high-resolution complex plots.

- Can use hourly, daily and monthly input profile schedules for each source emission.

- Works with the OSPM model, specifically to assess the "Street Canyon" effect resulting from the recirculation of air turbulence among buildings.

- Uses the GRS chemistry scheme, a semi-empirical photochemical model which includes the reactions of $\mathrm{NO}, \mathrm{NO}_{2}, \mathrm{O}_{3}$ and many organic compounds.

After gathering the data and in order to map an air-quality model, a highresolution grid was created with up to 150,000 virtual grid points across the territory, plus 50,000 points next to roads using "intelligent gridding" software capability. The result was a mean grid resolution of 35.2 metres in outlying parts of the city and an estimated mean grid resolution of 17.6 metres in the city centre in order to ensure higher accuracy. More than twelve processors were used, working constantly for 30 days. Figure 7 (left) shows the map of $\mathrm{NO}_{2}$ concentration levels after model calibration for 2008. Keep in mind that reality is more complex than the "typical profiles" or mean behaviours introduced in the model. Therefore, unusual traffic jams, fires, construction work, unknown emissions, and other situations can cause deviations between the models and actual data, meaning that model calibration must always be carried out.

Actual hourly data from the measurement stations was also compared with modelling results for virtual point detectors. Table 1 shows a comparison of annual mean values and Figure 6 contains a monthly example of hourly comparison.

\subsection{Characteristics and emissions of vehicles in Barcelona}

Since the road transport sector is the main emitter of pollutants, the PECQ established a clear difference with previous studies of vehicle emissions. A realworld characterisation of traffic was developed in order to find out what types of vehicles are driven around the city, as well as their emissions. It is important to mention that previous studies used the vehicle census of the city [5]. We will show below that there is a major "gap" between the traffic on the streets and what is listed in the city census via road tax. An example of this is that the vehicles that use the streets everyday are newer on average than the census vehicles. This is a key point for drawing up effective policies and calculating related $\mathrm{NO}_{\mathrm{X}}$ reductions. It is also important to have a better idea of actual emissions in order to obtain a better estimate in the air-dispersion model. 
Since it is a diffuse sector, traffic emissions must be determined indirectly, based on vehicle $\mathrm{km} / \mathrm{year}$, total number of vehicles, average speed, and methodologies based on emission factors (EF) by vehicle characteristics (fuel type, engine size, weight and technology of the vehicle), such as CORINAIR [6]/COPERT [7].

To improve EF methodology, Barcelona City Council conducted an ad-hoc study [8] over 32 days in May and June 2009, setting up 16 roadside points for measuring vehicle exhaust emissions, with a detector system called "RSD" (Remote Sensing Device [9]). This technology can detect pollutant emissions from vehicle exhaust pipes instantly and in a non-intrusive manner, using infrared and ultraviolet light according to the Lambert-Beer law. This means that vehicles do not have to modify their normal driving patterns and thousands of vehicle license plates and exhaust vehicle emission data can be gathered in just a few hours. The emission data shows the actual emissions of the vehicles, unlike other methodologies based on standard emission factors, and the license plate shows the vehicle type. This makes it possible to know the brand, vehicle model, technical characteristics (power, weight, fuel, age, etc.), and city of residence (census). We gathered 90,000 vehicle license plates and emissions data for more than 42,000 vehicles after RSD exhaust data validation.

This study revealed some important aspects:

- The average age of all vehicles is 5.7 years.

- The cars driving around the city are newer (with an avg. age of 5.53 years) than the city vehicle census (9.13 years). This does not mean that the census does not work properly. The difference only shows that older vehicles get driven less than newer vehicles or, in other words, that people who use their car every day tend to have newer vehicles.

- Petrol cars are older (7.58 years) than diesel cars (4.43 years) due to a social trend. In Spain, it is typical to buy a diesel car if your annual mileage is very high, so daily car users buy more diesel cars than weekend car users.

- The pre-EURO class displays an interesting behaviour pattern. $20 \%$ of the cars in the city vehicle census are pre-EURO; by contrast, the EURO class only represents $8 \%$ of cars driven daily in the city streets.

- The taxi fleet has an average age of 3.4 years, and the average age of trucks is 6.5 years.

- The most common fuel used by vehicles in the city is diesel at $55.1 \%$, followed by petrol at $44.1 \%$, biodiesel at $0.6 \%$ and, finally, natural gas at $0.3 \%$.

- $52 \%$ of the vehicles come from outside Barcelona city (they are not included in the municipal census). As for cars, $51 \%$ come from outside the city. In this group, $41 \%$ are petrol cars and $56 \%$ are diesel cars, since it is more cost-efficient to own a diesel car if your annual mileage is very high, as diesel is cheaper and more efficient than petrol. This makes sense considering that $62 \%$ [10] of daily car trips in Barcelona are made by people that live outside the city and commute in to work (or vice-versa). This is a very important point, since municipal policies focusing on diesel 
cars (emitting more pollutants than petrol cars) included in the municipal census will not be as effective as regional policies.

According to EURO class, 39.2\% of vehicles are EURO IV, 34.8\% are EURO III, $14.4 \%$ are EURO II, 5.5\% are EURO I and $5.6 \%$ are pre-EURO. It should be noted that the number of EURO V vehicles is symbolic $-0.4 \%-$ since this classification only applied to buses and trucks in 2009 (not to cars, vans or motorcycles) and the measurements were taken in mid-2009. The segments with the highest percentage of EURO II vehicle and older are petrol vans (LDV) with $44.2 \%$, diesel buses and coaches with $34.7 \%$, and petrol cars with $32.1 \%$.

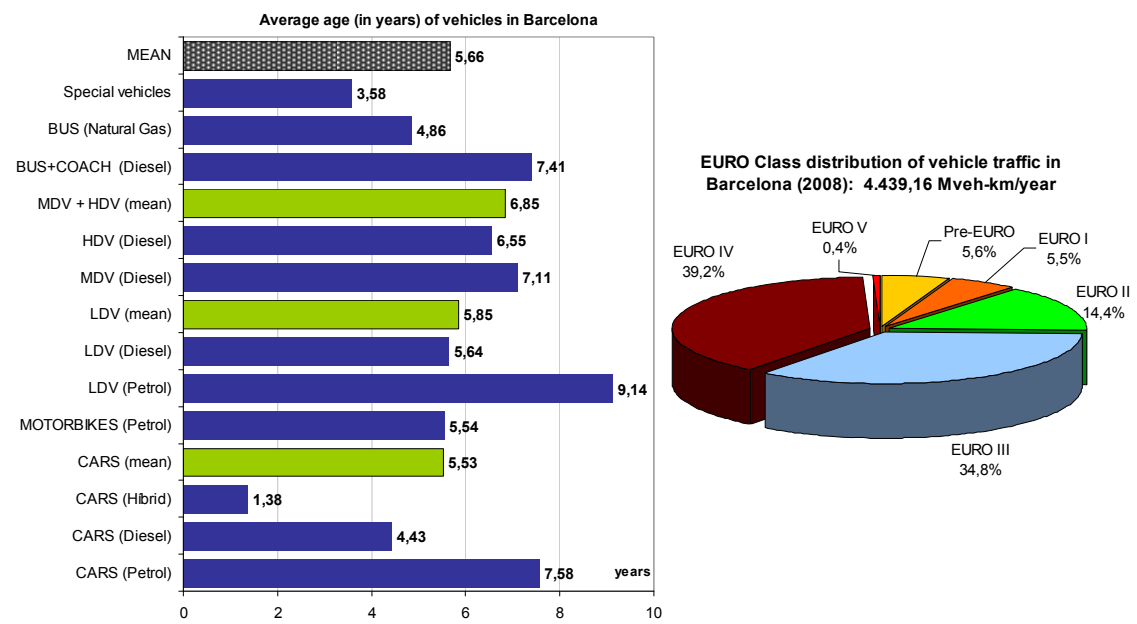

Figure 2: Average age of different categories of vehicles (left) and EURO class distribution of vehicles driving around city streets. (C) Barcelona Regional, 2010.

As mentioned above, we gathered actual exhaust pipe emissions from 42,000 vehicles driving around the streets of Barcelona, and we compared actual emissions from the "RSD" system with COPERT methodology. The average result was that RSD measured $16.2 \%$ higher $\mathrm{NO}_{\mathrm{X}}$ emissions than COPERT considering the same number of vehicles in city driving mode, with an average speed of $21.3 \mathrm{~km} / \mathrm{h}$ and the weather conditions for May/June.

RSD actual vehicle emission data with the annual share of vehicular traffic shows that $34.2 \%$ of vehicle $\mathrm{NO}_{\mathrm{X}}$ emissions are from cars $(29.3 \%$ from diesel cars and $4.9 \%$ from petrol cars), followed by vans (LDV) $17.4 \%$, medium and heavy trucks (MDV and HDV) 15.7\%, motorcycles and mopeds 12.3\% (in Barcelona, $22.8 \%$ of all private transport is by motorbike), private buses and coaches $12.2 \%$, and local public buses $8.2 \%$. The average emission factor for total traffic was 1.1297 grams of $\mathrm{NO}_{\mathrm{X}}$ per kilometre. Figure 3 shows total emissions and emission ratio by vehicle class, and Figure 4 contains the distribution according to mobility, vehicle emission and trips. 


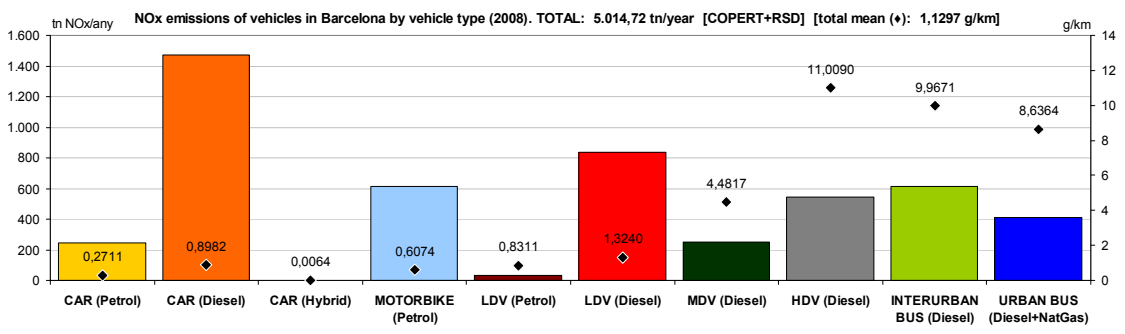

Figure 3: NOX emissions and emission ratio by vehicle type for Barcelona. (C) Barcelona Regional, 2010.

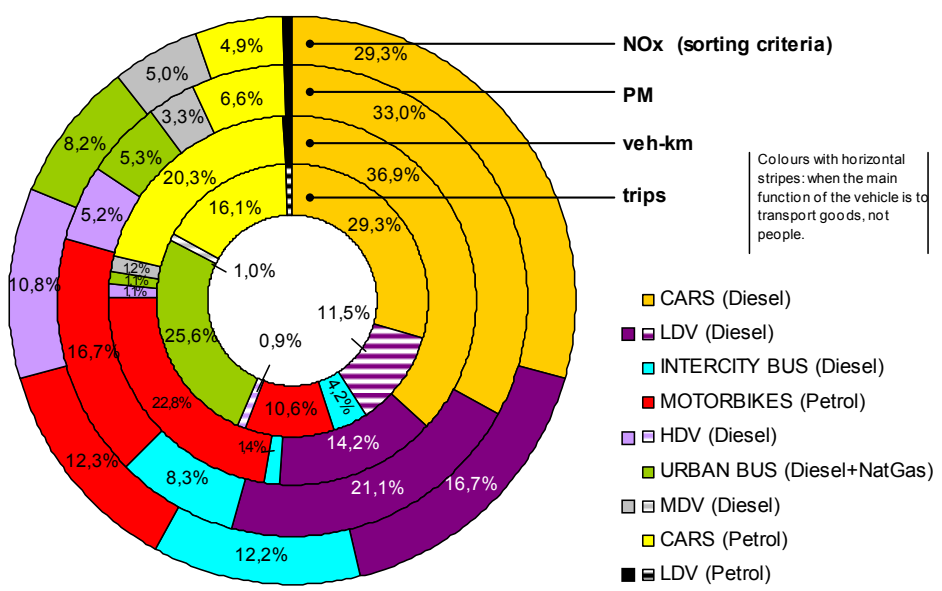

Figure 4: Related share of $\mathrm{NO}_{\mathrm{X}}$ emissions (sorting criteria), $\mathrm{PM}_{10}$ emissions, mobility (veh-km) and trips. (C) Barcelona Regional, 2010.

\subsection{Barcelona 2008 emissions inventory}

Database quality is one of the most important aspects of air-quality modelling. All the emission sources input into the air-dispersion model are shown below. The base-case year for the emissions inventory is 2008 .

- Road transport: we used the COPERT emission model plus the XTRA RSD recorded exhaust emission factors in order to include actual emissions from vehicles. Hourly, daily, weekly and monthly traffic profiles were also used.

- Residential and commercial: we used the CORINAIR emission factor to estimate $\mathrm{NO}_{\mathrm{X}}$ emissions from natural gas and LPG. Hourly and monthly profiles were also implemented for this sector.

- Industry and power plants: Actual emissions data for isolated emission sources with continuous environmental control was used. Other industrial emissions were estimated using CORINAIR methodology. 
- Port: Land traffic, sea traffic and auxiliary vehicles in Barcelona's Port were taken into account using the COPERT+XTRA RSD system for the first, and the CORINAIR methodology for the second and third. Monthly profiles were implemented for this sector.

- Airport: Barcelona Airport is $12 \mathrm{~km}$ from the city centre (outside the city limits). $\mathrm{NO}_{\mathrm{X}}$ emissions were estimated using CORINAIR methodology and taking into account LTO cycle for airplanes and auxiliary vehicles. Hourly and monthly profiles were used for the airport.

All these data provide an inventory of $\mathrm{NO}_{\mathrm{X}}$ emissions for Barcelona and surroundings covering $1,476 \mathrm{~km}^{2}$, of which Barcelona makes up only $7 \%$, with $102 \mathrm{~km}^{2}$. Air-quality modelling involves studying a larger area, since pollution does not respect municipal boundaries. Thus, total $\mathrm{NO}_{\mathrm{X}}$ emissions for the entire area covered were 34,186 tonnes in 2008, while $\mathrm{NO}_{\mathrm{X}}$ emissions for Barcelona city were $10,413 \mathrm{tn} / \mathrm{y}$.

As regards Barcelona emissions, vehicle are responsible for 5,015 th/y (4,299 according to COPERT plus 716 according to RSD), making up $48.2 \%$ of the city emissions. The second source of emissions was Barcelona Port, with 3,078 tonnes or $29.5 \%$ (2,512.5 for sea traffic plus 565,7 for land activity). The third source was industry and power plants, with $1,394 \mathrm{tn} / \mathrm{y}$ or $13.4 \%$. And, finally, the residential and services sectors, with $926 \mathrm{tn} / \mathrm{y}$ or $8.9 \%$. Figure 5 shows the georeferenced emissions inventory.

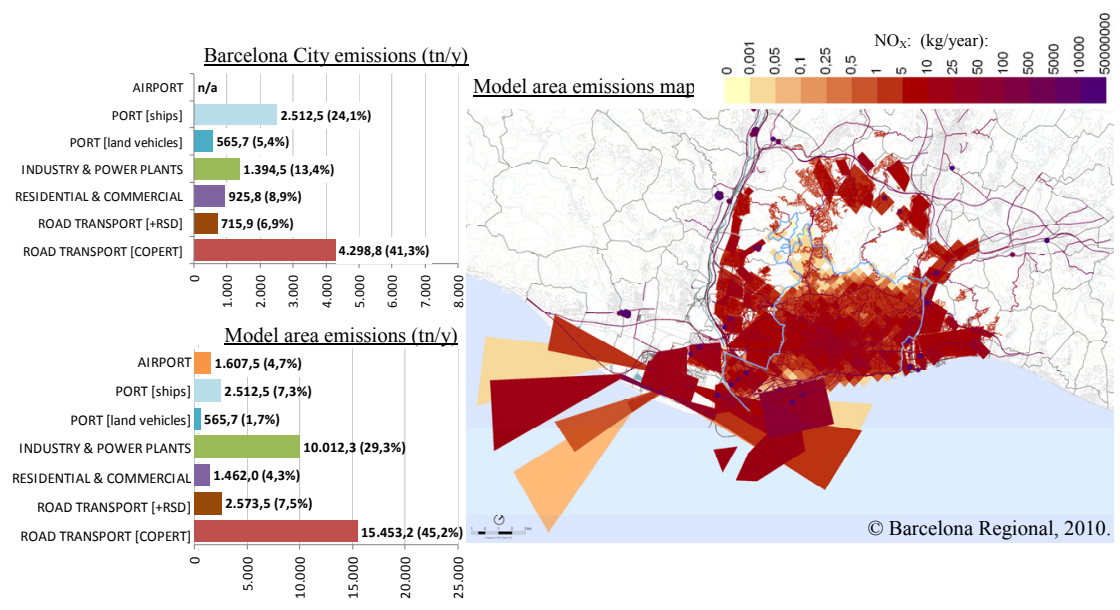

Figure 5: $\quad \mathrm{NO}_{2}$ emissions map for 2008 (right) and source apportionment for Barcelona city (top left) and for model area (bottom left).

\subsection{Structural inputs for the model}

Certain structural and meteorological inputs were also required in order to model air quality. This is described briefly below: 
- Meteorological data: actual hourly weather data for 2008 was used, taken from an urban weather station located in the city.

- Cartography: the topography and surface features of the area were taken from the database of the Catalonian Institute of Cartography.

- Road infrastructure: city network, highway network and bus network for Barcelona city and surrounding municipalities were introduced in the model with AAWT (annual average weekday traffic).

- 3-D building model: the 3-D Barcelona building model was used to model the street canyon effect.

\subsection{Background concentrations}

Background concentration levels were based on hourly data from a specific background concentration station located on the coast in the north of Catalonia (Cap de Creus, Girona), $140 \mathrm{~km}$ from Barcelona. The annual average concentration levels for 2008 were $4.26 \mu \mathrm{g} / \mathrm{m}^{3}$ for $\mathrm{NO}_{2}, 0.30 \mu \mathrm{g} / \mathrm{m}^{3}$ for $\mathrm{NO}$, and $74.4 \mu \mathrm{g} / \mathrm{m}^{3}$ for $\mathrm{O}_{3}[11]$.

\subsection{Modelling results and validation process}

By running the ADMS-Urban model for Barcelona with the geo-referenced emissions inventory and the structural inputs of the modelled area, we obtained an annual average $\mathrm{NO}_{2}$ concentration of $14 \%$ below actual concentration levels for virtual point receptors representing real measurement stations. Therefore, $5 \mu \mathrm{g} / \mathrm{m}^{3}$ of $\mathrm{NO}_{2}$ was added in order to calibrate the model - called "local background concentrations" - and the model was re-run.

After the calibration process, a very good estimate was obtained for all station measurement points. Table 1 shows the actual concentration levels for 2008 compared with the modelled values. We also obtained a very good model estimate for hourly concentration levels, as can be seen in Figure 6 .

Table 1: $\quad \mathrm{NO}_{2}$ model results vs. actual results.

\begin{tabular}{|c|c|c|c|c|}
\hline $\begin{array}{c}\text { Barcelona } \\
\text { monitoring sites }\end{array}$ & Type of location & $\begin{array}{c}\text { Actual } \mathrm{NO}_{2} \\
\left(\mu \mathrm{g} / \mathrm{m}^{3}\right)\end{array}$ & $\begin{array}{c}\text { Modelled } \mathrm{NO}_{2} \\
\left(\mu \mathrm{g} / \mathrm{m}^{3}\right)\end{array}$ & $\begin{array}{c}\text { Model/ } \\
\text { Actual }(\%)\end{array}$ \\
\hline Ciutadella & Urban background & 42.3 & 46.2 & $109 \%$ \\
\hline Vall d'Hebrón & Urban background & 36.5 & 37.7 & $103 \%$ \\
\hline Eixample & High traffic site & 65.4 & 63.2 & $97 \%$ \\
\hline Gràcia & High traffic site & 62.6 & 57.9 & $93 \%$ \\
\hline Poblenou & Moderate traffic site & 47.4 & 41.8 & $88 \%$ \\
\hline Sants & Moderate traffic site & 45.3 & 50.0 & $110 \%$ \\
\hline Average value & ---- & 49.9 & 49.5 & $99 \%$ \\
\hline
\end{tabular}

The air-dispersion model for Barcelona revealed than $65.6 \%$ of the average annual $\mathrm{NO}_{2}$ concentration level comes from traffic, $8.6 \%$ from the residential and services sector, $4.8 \%$ from industry and power generation, $2.1 \%$ from Barcelona Port, and only $0.1 \%$ from Barcelona Airport. In addition, $8.6 \%$ comes from background pollution and $10.1 \%$ comes from "local background concentrations" after the calibration process. 

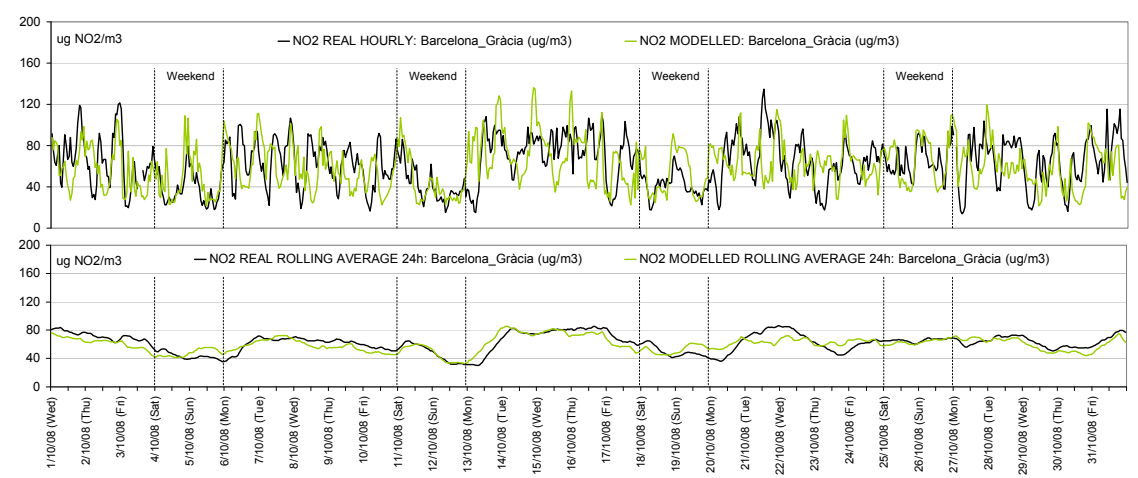

Figure 6: Hourly and 24-hour rolling average actual and modelled $\mathrm{NO}_{2}$ concentration levels for Gràcia measurement station in October 2008. (C) Barcelona Regional, 2010.

\section{Future scenario}

A Trend Scenario was developed to estimate the future air quality of the city, adding up the effects of the PECQ Action Plan. In general, certain foreseeable aspects were taken into consideration, including: future population, mobility and energy consumption considering new urban projects, social behaviour trends, new infrastructures and public transport systems to be developed over coming years, expected GDP growth, urban waste treatment, future power plants, Barcelona Port and Airport expansion plans, as well as technological improvements, especially in the transport sector with new EURO-class vehicles and the expected penetration of alternative-fuel vehicles.

A future reduction of $\mathrm{NO}_{\mathrm{X}}$ emissions of $26.3 \%$ is expected with the "PECQ Scenario" by 2020 (based on the "Trend Scenario" plus the "PECQ Action Plan"). This is equivalent to reducing 2,743 tn/year compared with existing technology. To predict future air quality, we have to assess the impact the PECQ Action Plan will have on future cars, with cleaner vehicles expected thanks to the technological improvements and EU regulations. So a reduction of $1,451 \mathrm{tn} / \mathrm{y}$ of emissions is expected by 2020 , equivalent to an overall reduction of emissions of $19.2 \%$ from 2008 emissions, or an annual average reduction rate of $1.8 \%$ from 2008 to 2020. We should point out that the Trend Scenario was calculated with an annual reduction rate of $0.5 \%$. Thus, the PECQ Action Plan will help speed up the reduction rate through projects such as: "Urban mobility action plan", "High-emissions radar", "Agreements with the business and transport sectors to reduce diesel use in vehicle fleets", "New more-efficient bus network", "Increasing low-emissions vehicles in the urban bus fleet", "Introducing new power sources for transport, including electric and gas vehicles", etc.

The future PECQ scenario fulfils current EU legislation concerning $\mathrm{NO}_{2}$ air pollution with the modelled annual average below $40 \mu \mathrm{g} / \mathrm{m}^{3}$ at all city monitoring sites. Table 2 shows expected future concentration levels, while Figure 7 shows the concentration maps for 2008 (left) and PECQ-2020 (right). 
Table 2: $\quad$ Expected $\mathrm{NO}_{2}$ concentration levels for future scenario in 2020.

\begin{tabular}{|c|c|c|c|}
\hline Monitoring site & Type & $\begin{array}{c}\mathbf{2 0 0 8} \\
\text { ACTUAL DATA } \\
{\left[\mathbf{N O}_{2} \mu \mathrm{g} / \mathrm{m}^{3}\right]}\end{array}$ & $\begin{array}{c}\text { PECQ-2020 } \\
\text { MODEL DATA } \\
{\left[\mathbf{N O}_{2} \mu \mathrm{g} / \mathrm{m}^{3}\right]}\end{array}$ \\
\hline Ciutadella & Urban background & 42.3 & $\mathbf{3 0 . 3}$ \\
\hline Vall d'Hebrón & Urban background & 36.5 & $\mathbf{2 4 . 6}$ \\
\hline Eixample & High traffic site & 65.4 & $\mathbf{3 9 . 9}$ \\
\hline Gràcia & High traffic site & 62.6 & $\mathbf{3 6 . 5}$ \\
\hline Poblenou & Moderate traffic site & 47.4 & $\mathbf{2 9 . 8}$ \\
\hline Sants & Moderate traffic site & 45.3 & $\mathbf{3 2 . 7}$ \\
\hline Average value & --- & $\mathbf{4 9 . 9}$ & $\mathbf{3 2 . 3}$ \\
\hline
\end{tabular}

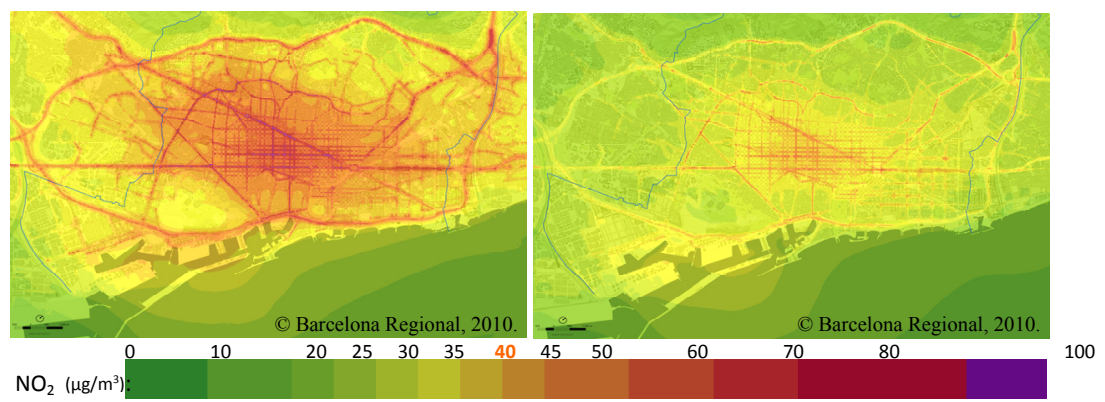

Figure 7: Annual average $\mathrm{NO}_{2}$ concentration map for 2008 (left) and 2020 (right).

\section{Discussion and conclusion}

The Barcelona air-dispersion model was drawn up as part of the Barcelona PECQ 2011-2020 (acronym in Catalan of Barcelona's Energy, Climate Change and Air Quality Plan). As discussed in the paper, transport is the main culprit for current high $\mathrm{NO}_{2}$ concentrations. This sector is responsible for $48.2 \%$ of $\mathrm{NO}_{\mathrm{X}}$ emissions, and also produces $65.6 \%$ of $\mathrm{NO}_{2}$ concentration levels, on an annual average. An important study has been conducted in Barcelona to determine what kinds of vehicles use the city streets every day and their exhaust emissions.

The Barcelona air-quality model has been a very important tool for drawing up the PECQ, for understanding local dispersion and detecting main pollutant sectors during the diagnosis stage, and for helping to assess and predict the impact of the measures on the city's air quality during the policy-making process.

With the adoption of the PECQ Action Plan for the year 2020, the Trend Scenario is expected to show an improvement in air quality, with annual $\mathrm{NO}_{2}$ average concentrations below $40 \mu \mathrm{g} / \mathrm{m}^{3}$ at all city stations. 


\section{Acknowledgements}

We would like to thank all the institutions that have contributed to the project, particularly to Barcelona Energy Agency and Mobility Depart. of Barcelona City Council, and especially to Barcelona Regional colleagues.

\section{References}

[1] Barcelona Regional \& Energy Agency of Barcelona, PECQ, Pla de l'Energia, el Canvi Climàtic i la Qualitat de l'aire de 2011-2020, March 2011, Barcelona city council, Barcelona. http://www.bcnregional.com/

[2] BOP, Butlletí Oficial de la Província de Barcelona, 14 of march 2006, Num. 62, Pag. 16-22. Barcelona.

[3] Barcelona Regional \& Barcelona City Council, PMEB. Pla de Millora Energètica de Barcelona. Ed. Ajuntament de Barcelona \& Agència d'Energia de Barcelona, 2002, Barcelona.

[4] CERC, http://www.cerc.co.uk/environmental-software/ADMS-Urbanmodel.html

[5] Barcelona Statistics Dept. http://www.bcn.cat/estadistica/catala/dades/ vehicles/index.htm

[6] EMEP/EEA air pollutant emission inventory guidebook - 2009, http://www.eea.europa.eu/publications/emep-eea-emission-inventoryguidebook-2009

[7] COPERT, http://www.emisia.com/copert/

[8] Barcelona Regional \& TechNet S.L., Caracterització del parc mòbil de la ciutat de Barcelona, October 2010, Ajuntament de Barcelona, Barcelona.

[9] Technet S.L. http://www.technetsl.es \& ESP, http://www.esp-global.com

[10] Serveis de Mobilitat Aj, de Barcelona. Dades bàsiques 2008. http://www.bcn.cat/mobilitatl

[11] EEA. European Environment Agency. Air quality statistics at reporting stations. http://www.eea.europa.eu/themes/air/airbase. 